POLSKA AKADEMIA NAUK - ZAKEAD BADANIA SSAKOW

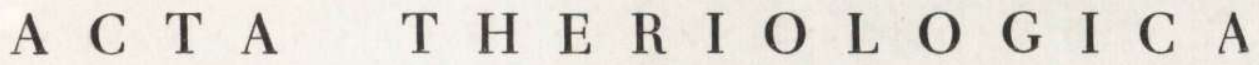 \\ VOL. IX, 18: $287-304$. \\ BIAŁOWIEŻA \\ 30.XII.1964
}

Gabriela B U J A L S K A

\section{Studies on the European Hare. IV. Variations in the Pelvis and Sacrum}

\author{
Badania nad zającem szarakiem. IV. Zmienność miednicy i kości \\ krzyżowej
}

[With 2 Plates, 3 Figs. \& 4 Tables]

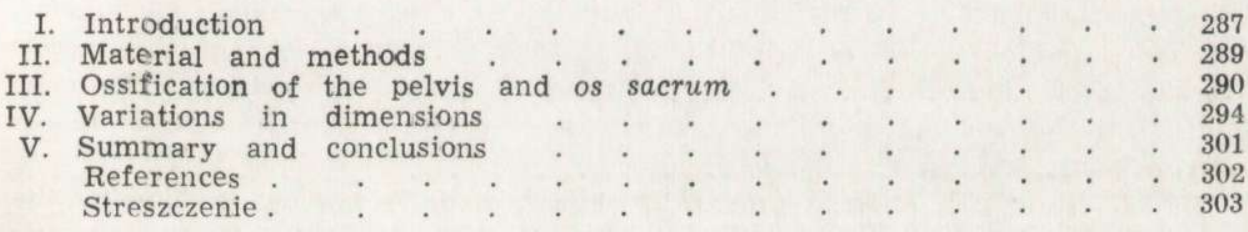

\section{INTRODUCTION}

The present work is concerned with variations of the pelvis and os sacrum of the hare due to age and differences between individuals.

I have dealt with this problem from the aspect of the function carried out by the pelvis during movement and in the process of reproduction in females.

No great interest was shown in the pelvis until the last century. Huxley (1875) in reviewing the pelvis of the crocodile, kangaroo and hare reached the conclusion that in the evolution of mammals the os coxae has a tendency to increase the acuteness of the angle formed with the sacral axis, so that the angle between the latter and the ilio-pubic axis is nearly $90^{\circ}$.

Lecke $(1884,1892)$ discussed the pelvis in insectivores, taking into consideration both philo- and ontogenetic development.

Chapman (1919) who contributed much that was new to literature, related the structure of the pelvis to the whole silhouette of the animal and its way of life. This is undoubtedly a pioneer work drawing attention to the influence of movement (e.g. digging tunnels in the case of certain rodents and insectivores) on the proportions of the pelvis.

The works by Frechkop (1947) follow a similar direction and relate the effect of the posture of Ungulata with the size and propartions of the pelvis. 
The work by Ossinskij (1959) in interesting in regard to the above question. The author discusses the pelvises of jumping animals (kangaroo, hare), runring animals (hedgehog, beaver, badger), animals moving about with quick steps the majority of dormice, martens) etc.

Sex differences were dealt with for the first time by van den Broek (1911) with regard to the pelvis of animalomorphous Primates. Much later on (1936) $\mathrm{G}$ a r d ner worked on the problem of sex dimorphism in mice.

Schultz (1949) described sex differences in the breadth of the pelvis sinus in Primates, the differences in the ratio of the length of the pubic bone to the length of the ischiadic bone being especially interesting. The indices obtained in this way were different for males and females in Macacus. On the other hand sex differences in Hylobatidae and Macacus are only slightly developed.

Guilday (1951) based his work on measurements of the pelvis of Microtus pensylvanicus, data on sex being known in this case. In doing so he introduced into literature the measurement of the breadth of ramus inferior ossis pubis in the narrowest place, thereby completely segregating males from females. Investigations made of Synaptomys and Clethrionomys revealed the same sex dimorphism, although in the case of Clethrionomys it is far less strongly marked.

Becker gave a comprehensive treatment of sex dimorphism in Muridae and Soricidae $(1954,1954 / 55)$. The description of sex dimorphism in rodents was continued by Dunmire (1955). He dealt with seven species (including Geomyidae, Sciuridae) and observed sex differences in the pelvis in each of the species examined. The index obtained from the ratio of length of ramus superior ossis pubis to the os ischium and the measurement of the minimum breadth of ramus inferior ossis pubis in Cricetidae completely separate the adult male and female specimens from each other. In Sciuridae, however, the sexes are divided by the ratio of the minimum breadth of the pubic bone to the length of the pubic symphysis.

$\mathrm{K}$ amel (1955) found that the ossa coxae in male dogs are far more massive. By applying several measurements describing, inter alia, the volume of the pelvis, he was able easily to distinguish between the pelvises of males and females.

$\mathrm{M}$ üller (1956) investigated each dimension for the first time, (e.g. length of ramus superior ossis pubis and length of os ischium) in relation to age. He showed that the development of the pelvis begins at the same level and that changes (e.g. in the length of os ischium in males) are not observed until after the animals attain sexual maturity.

Sex dimorphism in Lagomorpha (Lepus c. californicus) was dealt with by Le chleitner (1959). He examined 435 specimens of known sex. By using the index obtained from the ratio of length of ramus superior ossis pubis to the length of os ischium and measuring the minimum breadth of ramus inferior ossis pubis, he succeeded in distinguishing the pelvises of males and females with sufficient accuracy for practical purposes.

In Lepus e. europaeus sex differences in the proportions of the pelvis were from the ratio of breadth of ramus inferior ossis pubis to the length of symphysis pubica, he was able to distinguish between sexes in about $90 \%$ of the material.

The problem of the pelvis and os sacrum from the point of individual, age and sex differences was treated by Dolgov (1961). This author examined Soricidae 
- Sorex araneus, S. minutus and Neomys fodiens. He distinguished six different types of pelvis.

Finally the work by Herán (1962) on the morphology of the pelvis of Mustelidae, taking into consideration sex dimorphism, is deserving of attention.

\section{MATERIAL AND METHODS}

About 50 hares were shot in the Poznan province every month, which made it possible to obtain material with different age structures.

The pelvises were cleaned of muscles, then macerated by means of biological dissolution. The bones were next carefully dried to avoid damage to the symphyses pubico-ischium or the cartilaginous connections of the sacro-iliac joints. If some of them proved to be damaged they were joined together and included in the whole material, since no significant differences were found between glued and unglued pelvises.

I had a total of 604 pelvises at my disposal (306 $\sigma^{7} \sigma^{7}$ and 298 o $q$ ). I used a vernier scale for measurements.

After measuring a trial series of 46 pelvises of hares of the same age I took 9 out of 23 measurements which seemed to me to be the most characteristic:

1. Breadth of pelvis (at the broadest place on the exterior of ala ossis ilium).

2. Length of os coxae (from the margin of ala ossis ilium to tuber ischiadicum).

3. Minimum breadth of ramus inferior ossis pubis (on the external side).

4. Length of symphysis pubica (on the external side).

5. Length of ramus superior ossis pubis (from the proximal margin of acetabul$u m$ to the margin of symphysis).

6. The length of os ischium (from the proximal margin of acetabulum to tuber ischiadicum).

7. Breadth of os sacrum (on the ventral side between the two lower margins of facies auricularis).

8. Length of os sacrum (on the dorsal side from the basis to processus spinosus of the final sacral vertebra).

9. Weight of pelvis and os sacrum.

On account of the lack of significant differences between the size of the measurements of the left and right side of the pelvis, the left side only was measured in principle, measurement being made of the right side of the pelvis only in cases where th left was damaged.

The proportions of the pelvis were defined by means of the following indices:

1. $\frac{\text { Breadth of pelvis }}{\text { Length of os coxae }} \times 100$

Minimum breadth of ramus inferior ossis pubis

2. Length of symphysis pubica $\times 100$

3. $\frac{\text { Length of ramus superior ossis pubis }}{\text { Length of os ischium }} \times 100$

4. $\frac{\text { Breadth of os sacrum }}{\text { Length of os sacrum }} \times 100$ 
In addition to the traditional indices described in literature ( $\mathrm{Schultz}$, 1949; Dunmire, 1955) I introduced two new ones (indices 1 and 4).

Definition of the age of the hares examined was attended with certain difficulties. Stroh's method (1931) proved inadequate since it was found necessary to divide the material into several age groups. I therefore took as my basis the

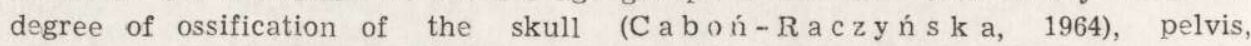
body weight of the hare (particularly in the case of young hares), taking into consideration the date they were shot (E m pel, 1957).

In effect four basic age groups were distinguished:

1. Very young hares (under 6 months old).

2. Young hares, well grown but not as yet mature $(6-8$ months old).

3. Mature hares ( 8 months to $1 \frac{1 / 2}{2}$ years old).

4. Old hares (over $1^{1 / 2}$ years old).

The first group contained hares with distinct sutures in the skull and pelvis, with body weight below $3 \mathrm{~kg}$. In the second group the sutures had closed over, but could still be distinctly seen. The sutures in group 3 were imperceptible, and in the fourth group all sutures, both those of skull and pelvis, were completely ossified.

The following sutures of the skull were taken into consideration: sut. frontalis, coronalis, sagittalis, and the sutures of the pelvis: pubico-ischiadico-coxal, coxoischiadic and the pubico-ischiadic-symphysis. In the event of difference between the degree of ossification of the skull and pelvis, age was established on the basis of the less ossified element.

\section{OSSIFICATION OF THE PELVIS AND OS SACRUM}

The order in which ossification of the pelvic sutures takes place would appear to depend on the kind of suture - its situation and importance to the normal functioning of the pelvis. The pelvis should be considered in this case not only from the aspect of its function during the process of reproduction in females, but also from the aspect of locomotor functions, uniform in both sexes.

The pubico-ischiadico-coxal suture is the first to ossify.

The coxo-ischiadic suture ossifies slightly later: in the second age group (6-8 months) it is usually ossified, although still distinct. During this period the consecutive vertebrae of the sacral bone, counting from the first to the last, begin to ossify.

Ossification of tuber ischiadicum and the margins of ala ossis ilium takes place even later. Twelve out of 82 pregnant females possessed the above elements still not ossified. This confirms the observations made by Lechleitner (1959) of Lepus c. californicus.

Symphysis pubica undergoes ossification the latest. The process of ossification was observed visually only, and its degree defined on the basis of the closing over of the suture connecting both pelvic bones. It would seem that ossification begins more or less in the centre of the whole length of the symphysis and progresses from the centre in 
the direction of the margins of arcus pubis and ramus ossis pubis. Closing of the sutures is not uniformly rapid in both directions - the suture in the region of arcus pubis ossifies more rapidly (Photo, 1 a, b, c, Plate III).

The suture on the inner side of the pelvis is the first to close over, which may suggest rapidity of ossification in the dorso-ventral plane.

The growth in length of ramus superior ossis pubis is connected with the ossification of symphysis. In males with ossified symphyses the length of ramus is not less than 21.0, and in females not less than $23.0 \mathrm{~mm}$. In the same way the minimum breadth of ramus inferior ossis pubis when the symphysis is ossified, is not less than $3.5 \mathrm{~mm}$ in males and $5.0 \mathrm{~mm}$ in females (Table 1).

\section{Table 1.}

Variation in length of ramus superior ossis pubis in males and females after complete ossification of symphysis (Numbers in each class expressed in percentages).

\begin{tabular}{|r|l|l|l|r|r|r|r|r|r|r|r|r|r|l|}
\hline $\operatorname{sex}$ & $3.5-$ & $4.0-$ & $4.5-$ & $5.0-$ & $5.5-$ & $6.0-$ & $6.5-$ & $7.0-$ & $7.5-$ & $8.0-$ & $8.5-$ & $9.0-$ & $n$ & $\bar{x}$ \\
\hline 06 & 3.9 & 4.4 & 4.9 & 5.4 & 5.9 & 5.4 & 6.9 & 7.4 & 7.9 & 5.4 & 8.9 & 9.5 & & \\
\hline 09 & 5.4 & 12.0 & 17.4 & 23.9 & 18.5 & 9.8 & 9.8 & 3.3 & & & & & 92 & 5.3 \\
\hline 7.8 & & & 9.4 & 5.6 & 17.0 & 22.6 & 13.2 & 18.8 & 1.9 & 1.9 & 5.6 & 53 & 6.7 \\
\hline
\end{tabular}

The fairly distinctly marked sex dimorphism, as regards the limits of variation of the above measurements, probably depends on the rate of ossification of symphysis. On the basis of a quantitative analysis of the material, assuming that the age structure of the hare population is similar in each sex, it may be taken that ossification of symphysis takes place earlier in males than in females, since the percentage of males with ossified symphysis is far greater, i. e. 28.2, while in females it is scarcely 14.6. It would seem that the process of ossification takes place after sexual maturity is reached. It is possible that this is a symptom of senescence. Out of 82 pregnant females, only 9 had ossified symphyses.

The sutures of the pelvis therefore ossify first, which makes the earliest possible junction of the various elements of the coxal bones possible. This is of great importance in putting into action movement functions of the pelvis. It is not until later that the symphysis ossifies, which is connected with the reproductive function of the pelvis in females.

I observed the way by which eminentia iliopectinea is developed. In young individuals a narrow and even prominence can be observed 
on the margin of the whole ramus superior ossis pubis (Photo. 2 a, Plate III). This margin occurs in both males and females chiefly in the first age group (only in sporadic cases in the second group). In successive stages the margin slowly disappears and increasingly large prominences appear (Photo. 2 b, c, Plate III).

Two basic types of prominence can be distinguished: with relatively large base and not very high (Photo. 3 a, Plate IV) and the reverse - with narrow base and very high (Photo. 3 b, Plate IV). Both kinds of prominence occur in females and males in different age groups.

A similarly loose connection with age is exhibited by the formation of crista sacralis mediana (the same was observed by Dolgov (1961) in the case of Soricidae. In all cases (with the exception of one) it progresses from the final vertebrae to the first.

A slight convexity can be observed at first on the shaft or processus spinosus of the fourth sacral vertebra (Photo. 4 a, Plate IV). This prominence next enlarges, extending to processus spinosus of the third vertebra (Photo. 4 b, Plate IV). The fusion of the third vertebra with the

Table 2.

Ossification process in crista sacralis mediana in different age groups.

\begin{tabular}{|c|c|c|c|c|}
\hline \multirow{2}{*}{ Sex } & hge group & II & III & IV \\
\cline { 2 - 3 } & Stage of the accreting & & $24.3 \%$ & $5.1 \%$ \\
\hline \multirow{2}{*}{$\delta 6$} & Partialiy & $15.3 \%$ & $29.2 \%$ & $5.1 \%$ \\
\hline \multirow{3}{*}{ fo } & Advanced & $23.1 \%$ & $24.1 \%$ & $13.3 \%$ \\
& Partialiy & $53.3 \%$ & $14.8 \%$ & $11.1 \%$ \\
\hline
\end{tabular}

second and the second with the first is similar (Photo. $4 \mathrm{c}$, Plate IV), but is delayed in phase in relation to the preceding one which has undergone fusion. A uniform sacral crest is thus formed. This phenomenon was noted in $330^{\pi} 0^{\pi}(11.5 \%)$ from the second, third and fourth groups, while 4.1 specimens were found among the females $(16.5 \%)$.

I distinguished in principle two stages of ossification of crista sacralis mediana: 1. partial ossification - i.e. from the moment of observing the first symptoms of ossification to the fusion of the two final vertebrae and 2. more advanced ossification, when the successive stages of each age group in the above stages is evidence of the very slight connection between this ossification and age (Table 2).

The fusion of processus spinosus of the sacral bone was described by Dolgov (1961) in Soricidae. The author distinguished as many 
as 10 types of ossification in Sorex araneus. I imagine that they should rather be considered as successive stages of ossification of crista sacralis mediana, which is further borne out by the table enclosed by Dolgov.

The angle of inclination of the spinous processes to the plane of the sacral bone decreases with the shift from front to back of this bone. Occasionally, however, the first process behaves slightly differently, since it is situated more or less vertically, and even at an obtuse angle. This would not appear to be connected with the sacralisation of the final lumbar vertebra.

An analysis of the pelvises of males supplies interesting information, since I found that characteristic prominences occur in many specimens, one on each ramus ossis ischii, as illustrated by Photo 5 . This is probably connected with the insertion of the ligament of the penis. A

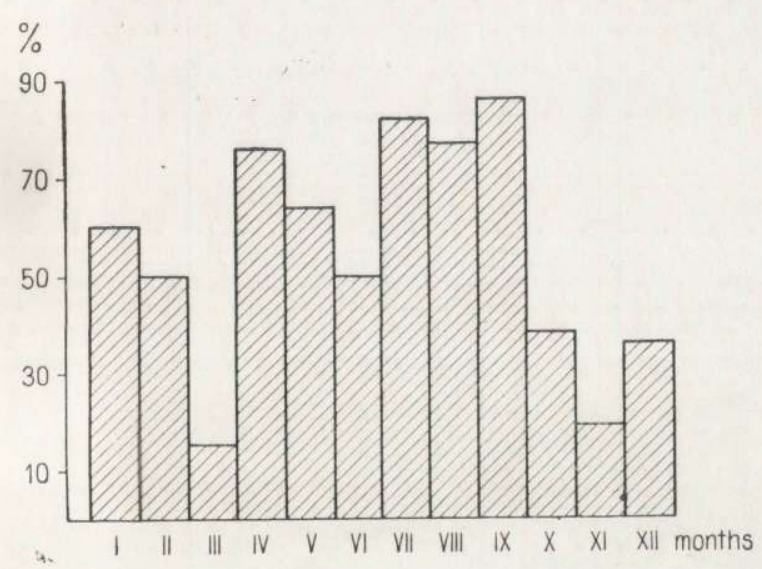

Fig. 1. Dynamics of occurrence in males of prominences on arcus ischium during the yearly cycle.

similar phenomenon was observed by $\mathrm{T}$ a ber (1958) in the blackand white-tailed deer and by Dolgov (1961) in Neomys fodiens.

This prominence does not appear until the third age group (in the second age group it occurs in one case only), while not all adult males in the third and fourth group posses it, in fact only in 110 specimens, that is, $50 \%$ of the material examined. It would not seem, however, (contrary to what $\mathrm{Taber}, 1956$ has written) that the size of this prominence is greatly dependent on age. It is true that its division into small, medium and large is distinct, but each of these groups includes hares of different ages. The percentage of males possessing this prominence increases, however, with age. In the second age group this prominence is present in $47 \sigma^{\top} \sigma^{\top}(38.8 \%)$, while in group four the figure is $64 \sigma^{x} \sigma^{x}(65.5 \%)$. 


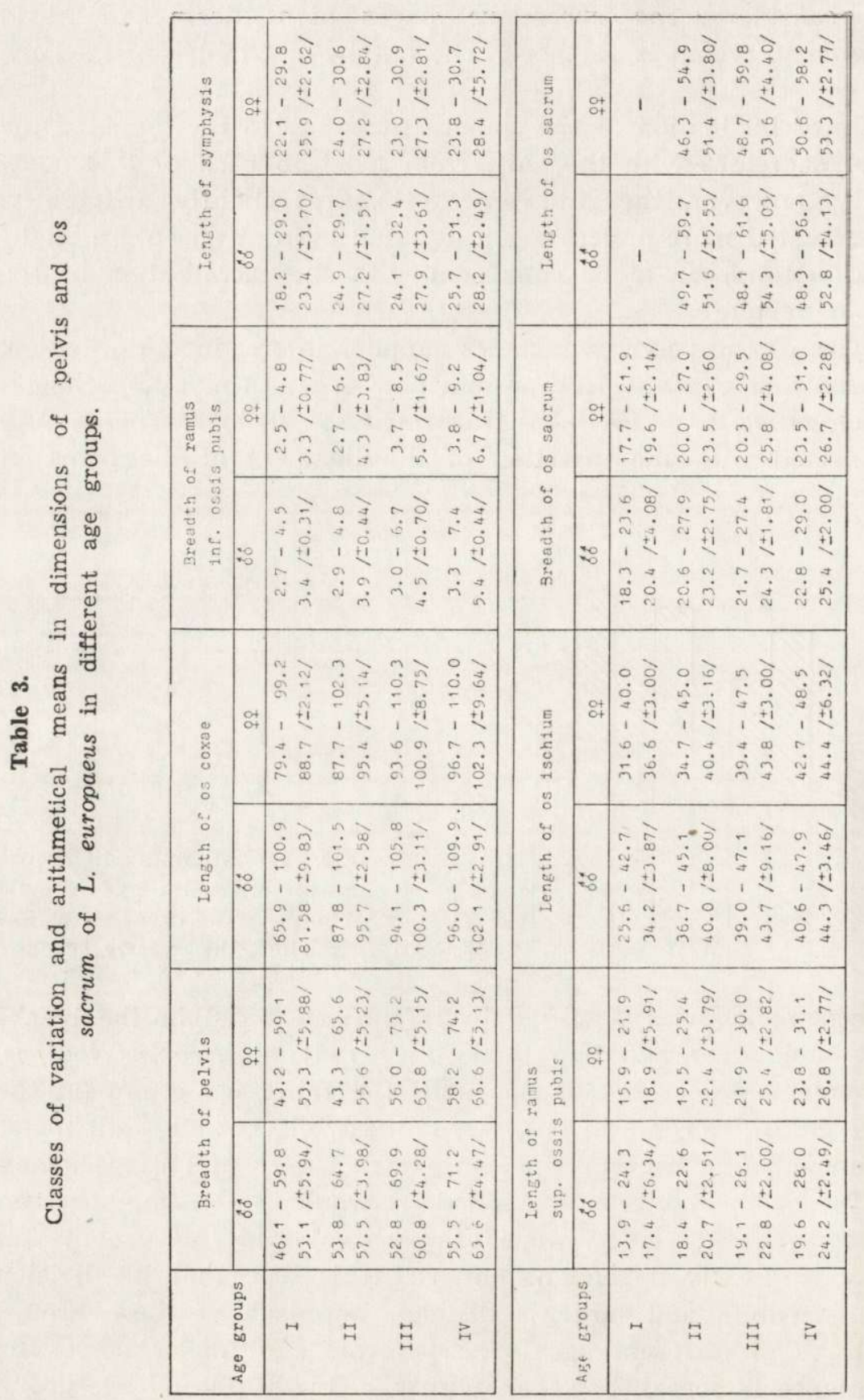


In addition I observed certain dynamics of occurrence of the above prominences over the course of the year (Fig. 1). The distinctly reduced percentage of males possessing this prominence in March and November, and the increase of their numbers during summer months from April to September) leads to the assumption that some degree of regularity exists. It will only be possible to draw more reliable conclusions after observing material from not one, but several, years.

\section{VARIATIONS IN DIMENSIONS}

The breadth of the pelvis is characterised by fairly distinct dimorphic differences, although the limits of variation of this dimension coincide to a considerable extent in both sexes (Table 3 ). Taken generally, the pelvis is broader in females of $I I I$ and $I V$ age groups as is illustrated by comparison of mean figures (differences are state ricuit).

In analogical measurements of Lepus e. europaeus Volf (1960) observed narrower limits of variation in adult males $(30-64 \mathrm{~mm}$.), but similar limits in females $(38-82 \mathrm{~mm}$.), and in addition the mean values of measurements were far smaller: for males $44.5 \mathrm{~mm}$., and $57.4 \mathrm{~mm}$. for females. It would seem that the material used by $\mathrm{V}$ ol $\mathrm{f}$ (1960) did not include pelvises 'of the oldest males, which is quite possible if the series of hares examined are relatively small $\left(250^{7} \sigma^{\pi}\right.$ and 25 우우.

In males, growth of pelvis breadth is more continuous in character (Fig. 2). Growth is more intensive in females in the third age group, which would appear to be connected with the sexual maturation period. Comparision of the means for the index obtained from the ratio of pelvic breadth to length of coxae (Fig. 3) also points to the distinct increase in breadth of the pelvis during the period in comparison with its length.

Dimorphic differences here would therefore appear to consist chiefly in the different rate of growth of this dimension.

The length of os coxae is, in principle, similar in males and females (Table 3). Although in the latter the limits of variation are wider and shifted in the direction of higher values, the mean values of this dimension in both sexes (with the exception of the first age group) are similar.

This result also is different from that described by Volf (1960). The limits of variation of the length of os coxae in adult males are from $89-1) 7 \mathrm{~mm}$. (mean $98.4 \mathrm{~mm}$.) and in females $99-108 \mathrm{~mm}$. (mean $98.1 \mathrm{~mm} .$.$) .$ 
The increase in length of os coxae is greater in males (Fig. 2) which is connected with the lower values of this dimension in the first age group.

Comparison of the mean figures from the first age group could provide evidence of the existence of certain differences in pelvic length
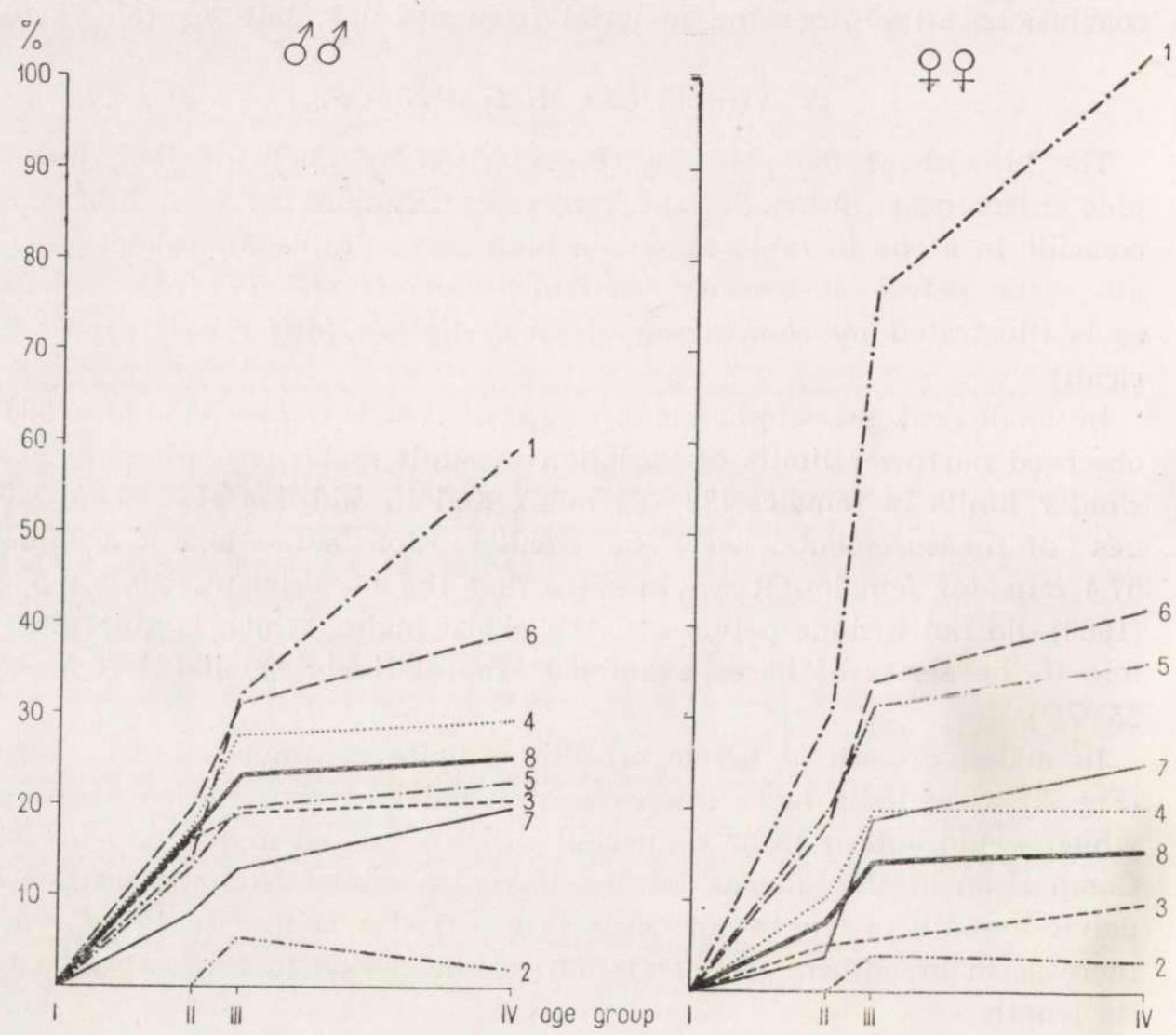

Fig. 2. Increase in percentages of dimensions $o_{i}^{i}$ pelvis and sacral bone in males and females in different age groups.

1 - breadth of ramus inferior ossis pubis, 2 - length of os sacrum, 3 - length of symphysis, 4 - length of os ischium, 5 - breadth of os sacrum, 6 - breadth of ramus superior ossis pubis, 7 - breadth of pelvis, 8 - length of os coxae.

bofore sexual maturity is reached, which would be contrary to the observations made by $\mathrm{M} u ̈ l l$ er. (1956) in Ondatra zibetica. The index obtained from the ratio of pelvic breadth to length of os coxae is, however, uniform in both sexes (similarly in fact to all the remaining indices in this age group). 
The breadth of ramus inferior ossis pubis is characterised by strongly accented sex dimorphism (Table 3). Sex dimorphism is expressed here not only by greater mean figures in females, than in males in each group, but also by the wider range of variation. Differences in females are statistically significant for age groups III and IV (S t u d e n t test).

The increase in breadth of ramus inferior ossis pubis, both in males and females, is continuous in character (Fig. 2). It reaches very high values in the case of females (exceeding the initial values by twice as much). The most distinct increase is noted after sexual maturity is attained (in the third age group), which is particularly distinct when observing the index obtained from the ratio of breadth of ramus inferior ossis pubis to length of symphysis (Fig. 3). Despite such great differences in the mean values and the rate of growth, the limits of variation of this dimension coincide in males and females and complete segregation of the sexes on this basis is impossible. This measurement separated the sexes in Synaptomys (Guilday, 1951) and certain rodents (D unmire, 1955), in Lepus e. europaeus (Volf, 1961), Martes foina (H e r á ň, 1962), but was not sufficient to distinguish between sexes in Martes martes and Mustella erminea ( $\mathrm{H}$ e $\mathrm{r}$ á n̆, 1962).

It is interesting that in the hare material described by Volf (1960) distinction between the sexes by means of using the index obtained from the ratio of breadth of ramus inferior ossis pubis to the length of symphysis is possible in 17 cases $(34 \%)$, while in the present material only in $22(8.5 \%)$. When the measurement of length of processus lateralis ossis ischium was used in addition, Volf (l.c.) succeeded in distinguishing sex in about $90 \%$ of the specimens. In my case this was impossible.

I assume that Volf (l.c.) must have had in the material which he used specimens of different age - this is clearly borne out by the photograph of pelvises of a male and female which he gives, with different breadth of ramus inferior ossis pubis and different degree of ossification. This dimension, as is clear from observations of the present material, may continue to increase for several months after sexual maturity is attained, hence the fact of such great sex differences in this dimension may suggest a difference of several months in age.

The length of symphysis is, in principle, similar in both sexes (Table 3). The limits of variation in males in the second and third age groups, however, have higher values. This might suggest a tendency in their case to attain greater lengths of symphysis [this would agree 

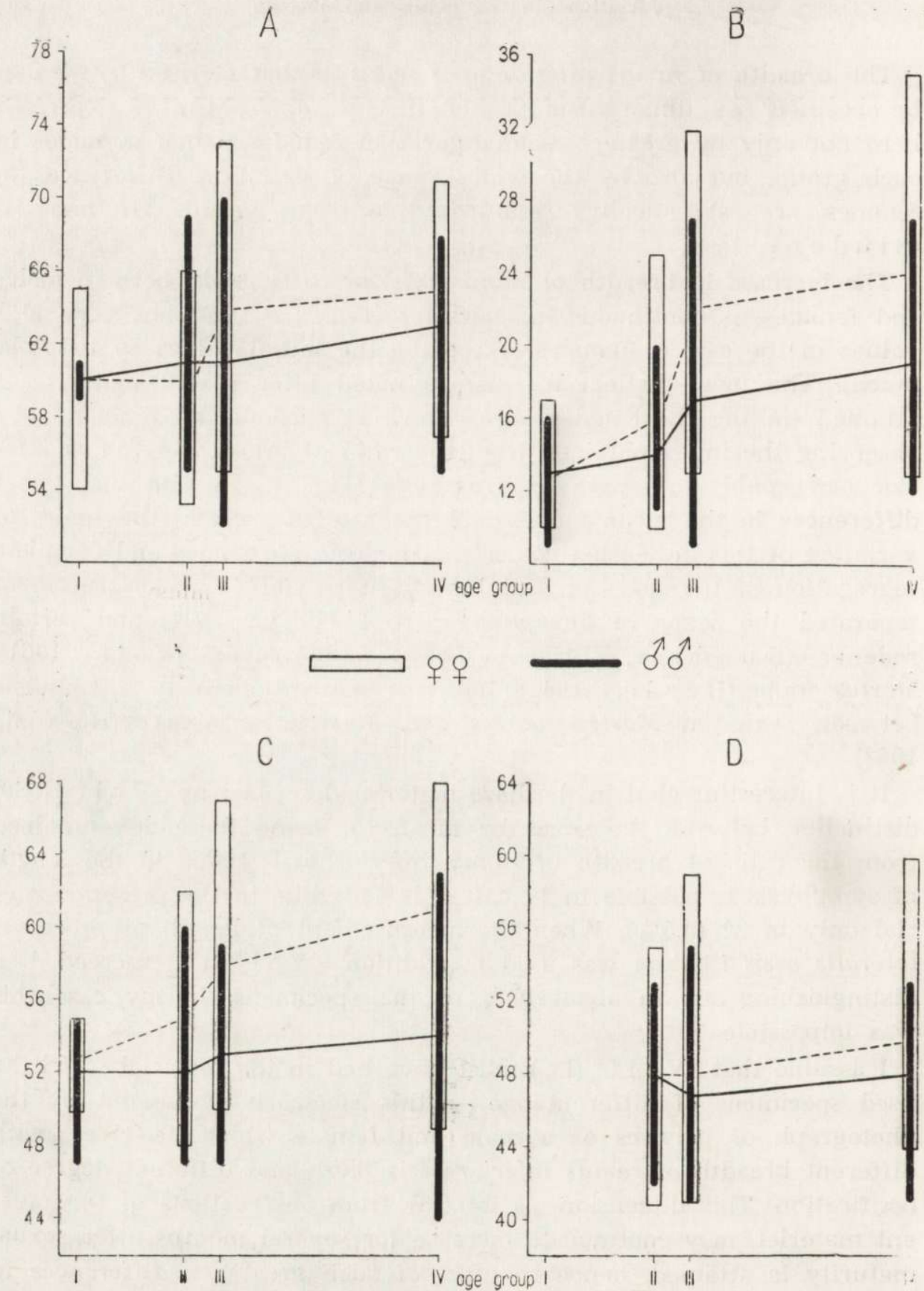

D

Fig. 3. Classes of variation and arithmetical means of some indices in males and females in different age groups.
A $-\frac{\text { Breadth of pelvis }}{\text { Length of os coxae }} \times 100$,
C $-\frac{\text { Length of ramus sup. os. pubis }}{\text { Length of os ischium }} \times 100$.
B $-\frac{\text { Breadth of ramus inf. os. pubis }}{\text { Lenght of symphysis }} \times 100, \mathrm{D}-\frac{\text { Breadth of os sacrum }}{\text { Length of os sacrum }} \times 100$, 
with Volf's observations (1960) of the hare and is contrary to what D unmire (1955) gives for Citellus], but this is not confirmed by comparison of mean values. Observations of the above material in fact rather indicates considerable similarity of length of symphysis in males and females.

The length of ramus superior ossis pubis in the two first age groups (Table 3) is similar. Absence of sex dimorphism in the structure of the skeleton before the maturation period would appear completely understandable as depending on the presence of the sex hormones - testosteron and oestrogen (D u nmire, 1955, Peyre, 1958). It is not until the third age group that the mean values of the dimension increase considerable in the case of females and are significantly different in comparison with males. The increase noted here is intensive and indicates the part played by this bone in the process of reproduction. In males growth is continuous in character (Fig. 2).

Similar results referring to the attainment by females of greater lengths of ramus superior ossis pubis were obtained by other authors: Schultz (1949) in Primates, Dunmire (1955) in rodents, Mülle $\mathrm{r}$ (1956) in Ondatra zibetica and T a be r (1958) in Cervinae. Differences in the dimensions in both sexes described by these authors were, however, far more distinct.

The length of os ischium does not exhibit dimorphic differences (Table 3). Limits of variation for adult specimens in Volf's (1960) material were, for males, $36-44 \mathrm{~mm}$. (mean $41.7 \mathrm{~mm}$.) and for females, 35-44 mm. (mean $41.1 \mathrm{~mm}$.). They are therefore shifted in the direction of smaller values in comparison with the material which I worked on.

The different increase in length noted in males and females (Fig. 2) results from the different values of this dimension in the first age group such as we note in both sexes (It may be due to the small number of individuals in this age group).

The mean value of the index obtained from the ratio of length of ramus superior ossis pubis to the length of the os ischium (Fig. 3) is in fact different in the males and females in each age group, nevertheless the limits of variation are, in principle, similar and complete segregation of the sexes on this basis is impossible. Even if those specimens among the males with an index higher than 63 are excluded, sex can be identified in scarcely $15 \%$ of the material composed of adult females and in $1 \%$ in the case of adult males. In the case of females the upper limit of variation is important (over 63), and in males the lower limit (below 48), not encountered in the opposite sex. 
The index referred to above in many cases, such as in Microtus californicus, Citellus beecheyi - D un mire (1955), Lepus c. californicus - Lechleitner (1956), Lepus e. europaeus - Volf (1960) differed to a considerable degree in males and females, so that segregation of sexes was sufficiently accurate for practical purposes.

The breadth of os sacrum in the first and second age group is similar in both sexes: this refers both to mean values and to the limits of variation (Table 3 ).

It is not until the third age group that the increase in breadth in females is very distinct (and statistically significant), while in males it continues to be fairly uniform (Fig. 2, 3).

The length of os sacrum is similar in males and females (Table 3). The picture of growth is incomplete, since data from the first group are missing, but it is any case relatively small (Fig. 2).

The fact that the mean length of os sacrum in males in the fourth age group is reduced is remarkable, but would appear to result from the relatively small number of specimens of this age examined (a large number had damaged sacral bones).

\section{Table 4.}

Variations in joint weight of pelvis and os sacrum.

\begin{tabular}{|c|c|c|c|c|c|c|c|c|c|c|c|}
\hline Sex & $\begin{array}{l}\text { i.ge } \\
\text { group }\end{array}$ & $\begin{array}{l}13.0= \\
14.9\end{array}$ & $\begin{array}{l}15.0- \\
16.9\end{array}$ & $\begin{array}{l}17.0- \\
18.9\end{array}$ & $\begin{array}{l}19.0- \\
20.9\end{array}$ & $\begin{array}{l}21.0- \\
22.9\end{array}$ & $\begin{array}{l}23.0- \\
24.9\end{array}$ & $\begin{array}{l}25.0- \\
25.9\end{array}$ & $\begin{array}{l}27.0- \\
28.9\end{array}$ & $\begin{array}{l}29.0- \\
30.9\end{array}$ & $\bar{x}$ \\
\hline 66 & $\begin{array}{r}\text { II } \\
\text { III } \\
\text { IV }\end{array}$ & & $\begin{array}{l}5 \\
1\end{array}$ & $\begin{array}{l}5 \\
4\end{array}$ & $\begin{array}{l}18 \\
12\end{array}$ & $\begin{array}{l}17 \\
11\end{array}$ & $\begin{array}{r}6 \\
11\end{array}$ & $\begin{array}{l}2 \\
9\end{array}$ & 2 & & $\begin{array}{l}21.1 \\
21.0\end{array}$ \\
\hline$q 9$ & $\begin{array}{r}\text { II } \\
\text { III } \\
\text { IV }\end{array}$ & 1 & $\begin{array}{l}1 \\
1 \\
1\end{array}$ & $\begin{array}{l}9 \\
3 \\
2\end{array}$ & $\begin{array}{r}3 \\
11 \\
2\end{array}$ & $\begin{array}{r}1 \\
12 \\
10\end{array}$ & $\begin{array}{r}1 \\
9 \\
19\end{array}$ & $\begin{array}{l}4 \\
6\end{array}$ & 1 & 1 & $\begin{array}{l}18.5 \\
20.2 \\
23.5\end{array}$ \\
\hline
\end{tabular}

The weight of the pelvis and os sacrum does not exhibit distinct sex differences, although it is slightly greater in females after sexual maturity is attained (Table 4). Differences in the fourth age group are statistically significant.

In addition the coefficients of correlation for certain measurements were calculated, separately for each sex. In all cases these coefficients were different.

For the length and breadth of the pelvis in males this coefficient was 0.51 , and in females it is considerable greater, that is, 0.64 .

The minimum breadth of ramus inferior ossis pubis and breadth of os sacrum has a greater coefficient of correlation in males - 0.64 , while in females it scarcely attains 0.54 . 
The minimum breadth of ramus inferior ossis pubis and breadth of pelvic bone are characterised in both sexes by a fairly high coefficient of correlation, 0.58 in males and 0.69 in females.

The length of pelvis and pubic symphysis, on the other hand, are correlated with each other to a far lesser degree. In males the coefficient of correlation is scarcely 0.33 , and in females 0.50 .

Particularly great differences in the value of the coefficient of correlation in males and females occur in the measurement of breadth of ramus superior and inferior ossis pubis. In males this coefficient is 0.49 , in females 0.81 .

It may therefore be said that in general, with the exception of one case (with minimum breadth of ramus inferior ossis pubis and breadth os sacrum) the coefficients of correlation of each measurement are greater in females. This is evidence of the greater interdependence of growth of these dimensions.

\section{SUMMARY AND CONCLUSIONS}

Analysis of the pelvises and sacral bones of 604 hares (306 $\sigma^{x} \sigma^{x}$ and 298 o $q$ ) from Western Poland supplied data on variation according to age and differences between individuals in the above mentioned elements of the skeleton.

On the basis of visual observation of pelvises and sacral bones it was established that the order in which ossification of the sutures of the pelvis takes place depends on its situation. The first to ossify are the sutures permitting the various elements of the ossa coxae to link up - the last is symphysis pubica, this process occurring slightly earlier in males than in females.

Ossification of crista sacralis mediana progresses caudocranially towards the os sacrum and does not depend on either the sex or age of the hare.

Characteristic prominences occur on the margins of ramus ossis ischii in $50 \%$ of the adult hares. The percentage of males possessing this prominence increases with age.

The rate of growth and variations in nine measurements of the pelvis and sacral bone were described. Differences between the mean values of measurements in different age groups in males and females are in principle slight, and the limits of variation coincide to a considerable extent.

On the other hand the very intensive increase (in females) in the breadth of the pelvis, length of ramus superior and breadth of ramus inferior ossis pubis and the breadth of os sacrum during the period of sexual maturation (and even immediately before it, as in the case of ramus inferior ossis pubis) in comparison with the relatively uniform growth of these dimensions in males indicates the existence of a certain sex dimorphism, the more so that in the youngest hares (about six months old) the mean values of all indices are uniform in both sexes (only the index of the ratio of breadth to length of os sacrum differs slightly in males and females), 
Sex differences in measurements of the pelvis and sacral bone of the hare consist chiefly in the different growth dynamics of individuals of both sexes.

Acknowledgments: The author gratefully acknowledges the stimulating quidance of Professor Dr. August Dehnel during this research and the valuable suggestions made by Dr. Z. Pucek concerning the manuscript.

\section{REFERENCES}

1. Becker, K., 1954b: Beiträge zur Geschlechtsbestimmung von Mäusen (Muridae) nach Skelettresten aus Eulengewöllen. Zool. Jb. (Syst.), 82, 5: $463-472$.

2. Becker, K., 1954/55: Uber Art und Geschlechtsunterschiede am Becken einheimischer Spitzmäuse (Soricidae). Z. Säugetierkde., 20: 78-88.

3. Broek, A. J. P. v. d., 1914: Studien zur Morphologie des Primatenbeckers. Morphol. Jahrb., 49: 1-118. (after $\mathrm{Ch}$ a p m a n, 1919).

4. Caboń-R a czyńska, K., 1964: Studies on the European hare. III. Morphological variability of the skull. Acta theriol., 9, 17: 249-285.

5. Chapman, R. N., 1919: A study of the correlation of the pelvic structure and the habits of certain burrowing mammals. Am. J. Anat., 25, 2: 185-208.

6. Dolgov, V. A., 1961: Ob izmenčivosti nekotoryh kostei postkranialnogo skeleta zemleroek (Mammalia, Soricidae). Acta theriol., 5, 15: 203-227.

7. Dunmire, W., 1955: Sexdimorphism in the pelvis of rodents. J. Mamm., $36,3: 356-361$.

8. Empe 1, W., 1957: Zmiany w morfologii czaszki królika dzikiego (Oryctolagus cuniculus L.) związane z wiekiem i rozmieszczeniem na terenie Polski Folia morphol., 8, 3: 169-194.

9. Frechkop, S., 1947: Notes sur le mammiferès, XxX. De la forme du bassin des Ongulés. Bull. Mus. Nat. Belg., 23, 32: 1-10.

10. G a rdner, W. U., 1936: Sexual dimorphism of the mouse, the effect of estrogenic hormones upon the pelvis and upon the development of scrotal hernias. Am. J. Anat., 59, 4: 459-478.

11. Guilday, J. E., 1951: Sexual dimorphism in the pelvic girdle of Microtus pensylvanicus. J. Mamm., 32, 2: 216-217.

12. Herá n̆, I., 1962: Přispèvek $\mathrm{k}$ pozńani morfologie pánve lasicevitých šelem. Zool. Listy, 11, 1: 35-52.

13. Huxley, T. H., 1875: On the characters of the pelvis in the Mammalia, and the conclusion respecting the origin of the Mammalia which may be based on them. Proc. Roy. Soc. Lond.: 395-405. (after $\mathrm{Ch}$ a pm a n, 1919)

14. Kame1, S., 1955: Sex determination from the innominate bone in the dog. Brit. Vet. J., 111, 8: 347-349.

15. Lechleitner, R. R., 1959: Sex ratio, age classes and reproduction of the black-tailed jack rabbit. J. Mamm., 40, 1: 63-81.

16. Le cke, W., 1884: Mammalia, pelvis, Bronn, Klassen und Ordnung des Tierreichs. Bd. 6, S. 571 (after $\mathrm{Ch}$ a p m a n, 1919).

17. Lecke, W., 1892: Mammalia, Myology. Bronn, Klassen und Ordnung des Tierreiches. Bd. 6, S. 784 (after $\mathrm{Ch}$ a p m an, 1919).

18. M ülle r, G., 1956: Geschlechtsunterschiede am Becken des Bisamratte, Ondatra zibethica (L i n n é, 1766). Säugetierkdl. Mitt., 4, 4: 150-153.

19. Ossinskij, P. A., 1959: O haraktere sopražennyh dviženij taza i pozvonočnika u nekotoryh mlekopitajuščih. Zool. Ž., 38, 11: 1711-1718. 
20. Schultz, A. H., 1949: Sex differences in the pelvis of primates. Am. J. physiol. Anthrop. Philad., 7, 19: 401-423.

21. Stroh, G., 1931: Zwei sichere Altersmerkmale beim Hasen. Berlin. Tierärztl. Wschr., 12.

22. Taber, R. D., 1956: Characteristics of the pelvic girdle in relation to sex in black-tailed and white-tailed deer. Calif. Fish. Game.. 42, 1: 15-21.

23.. Volf, J.. 1960: Geschlechtsunterschiede beim Feldhasen, Lepus e. europeus $\mathrm{P}$ a 11 a s, 1778. Säugetierkdl. Mitt. 8, 1/2: 39-43.

Polish Academy of Sciences, Mammals Research Institute, Białowieża, Poland.

\section{STRESZCZENIE}

Opisany materiał składa się z 604 (306 $\sigma^{x} \sigma^{x}$ i 298 ๆ \%) miednic i kości krzyżowych zająca szaraka, Lepus europaeus Pallas, 1778. Zające pochodzą z woj. poznańskiego, gdzie od grudnia 1958 do lutego 1960 prowadzony był regularny odstrzał.

Wiek oznaczano na podstawie kostnienia szwów czaszki, miednicy, ciężaru ciała, uwzględniając jednocześnie datę odstrzału zająca. W efekcie wyróżniono cztery grupy wiekowe: 1) zające bardzo młode (poniżej 6 miesięcy), 2) zające młode, wyrośnięte, ale jeszcze nie dojrzałe ( $6-8$ miesięcy), 3) zające dojrzałe (8 miesięcy do $1^{1 / 2}$ roku), zające stare (powyżej $1^{1 / 2}$ roku).

$\mathrm{Na}$ podstawie obserwacji wizualnych miednicy i kości krzyżowych stwierdzono, że kolejność kostnienia szwów miednicy jest uzależniona od położenia szwu. Najpierw kostnieją szwy umożliwiające zespolenie poszczególnych elementów kości biodrowych. Najpóźniej kostnieje symphysis pubica poczynając od środka długości (Tabela 1, Fot. 1 a, b, c), przy czym kostnienie to następuje wcześniej u samców, niż u samic.

Kostnienie crista sacralis mediana postępuje od tyłu ku przodowi os sacrum (Tabela 4, Fot. 1 a, b, c) i nie zależy od wieku, ani płci zająca (Tab. 2).

U $50 \%$ dojrzałych samców występują na brzegu ramus ossis ischii charakterystyczne wyniosłości (Tabela 5, Fig. 1). Procent samców posiadających tę wyniosłość zwiększa się z wiekiem.

Stosując 9 pomiarów i 4 wskaźniki autorka stwierdziła, że szerokość miednicy, ramus inferior ossis pubis, os sacrum i długość ramus superior ossis pubis charakteryzują się bardzo intensywnym przyrostem w okresie dojrzewania płciowego. Analogiczne wymiary u samców rosną jednostajnie (Tabela 7, Ryc. 1, 2).

Srednie wartości wymienionych wymiarów różnią się znacznie u samców i samic, ale granice zmienności pokrywają się (Tab. 3) tak, że odróżnienie płci w najlepszym przypadku (na podstawie wskaźnika otrzymanego ze stosunku dlugości ramus superior ossis pubis do długości os ischium) możliwe jest zaledwie u $16 \%$ osobników.

W wymiarach dlugości os coxae, ischium, sacrum $i$ symphysis pubica nie zanotowano żadnych różnic dymorficznych. Duże różnice zaobserwowano natomiast we wspólczynnikach korelacji niektórych wymiarów u samców i samic.

Dosyć wyraźne rozbieżności pomiędzy graniçami zmienności niektórych pomia- 
rów opisanych przez Volf a (1960) u Lepus e. europaeus oraz opisanymi przez autorkę mogłyby świadczyć, że są to dwie różne rasy zająca. Należy jednak liczyć się z tym, że Volf opracował zbyt małą serię miednic ( 25 or $\sigma^{7}$ i 25 o 우), aby można było wyciągnąć wiarygodne wnioski.

Reasumując autorka stwierdziła, że dymorfizm płciowy miednicy i kości krzyżowej zająca szaraka wyraża się przede wszystkim w różnej dynamice wzrostu oraz zmian poszczególnych pomiarów i wskaźników u samców i samic.

\section{EXPLANATION OF PLATES}

Plate III.

Photo. 1. Successive stages of ossification of symphysis pubica: a - initial, b - partial, c - advanced.

Photo, 2. Successive stages of individuation of eminentia iliopectinea: a - early, b - medium, - late.

Plate IV.

Photo. 3. Two types of eminentia iliopectinea: a -- foliate, b - crooked.

Photo. 4. Successive phases of fusion of crista sacralis mediana a - initial, b - partial, c - advanced.

Photo. 5. Pelvis of a male with prominences on arcus ischium. 

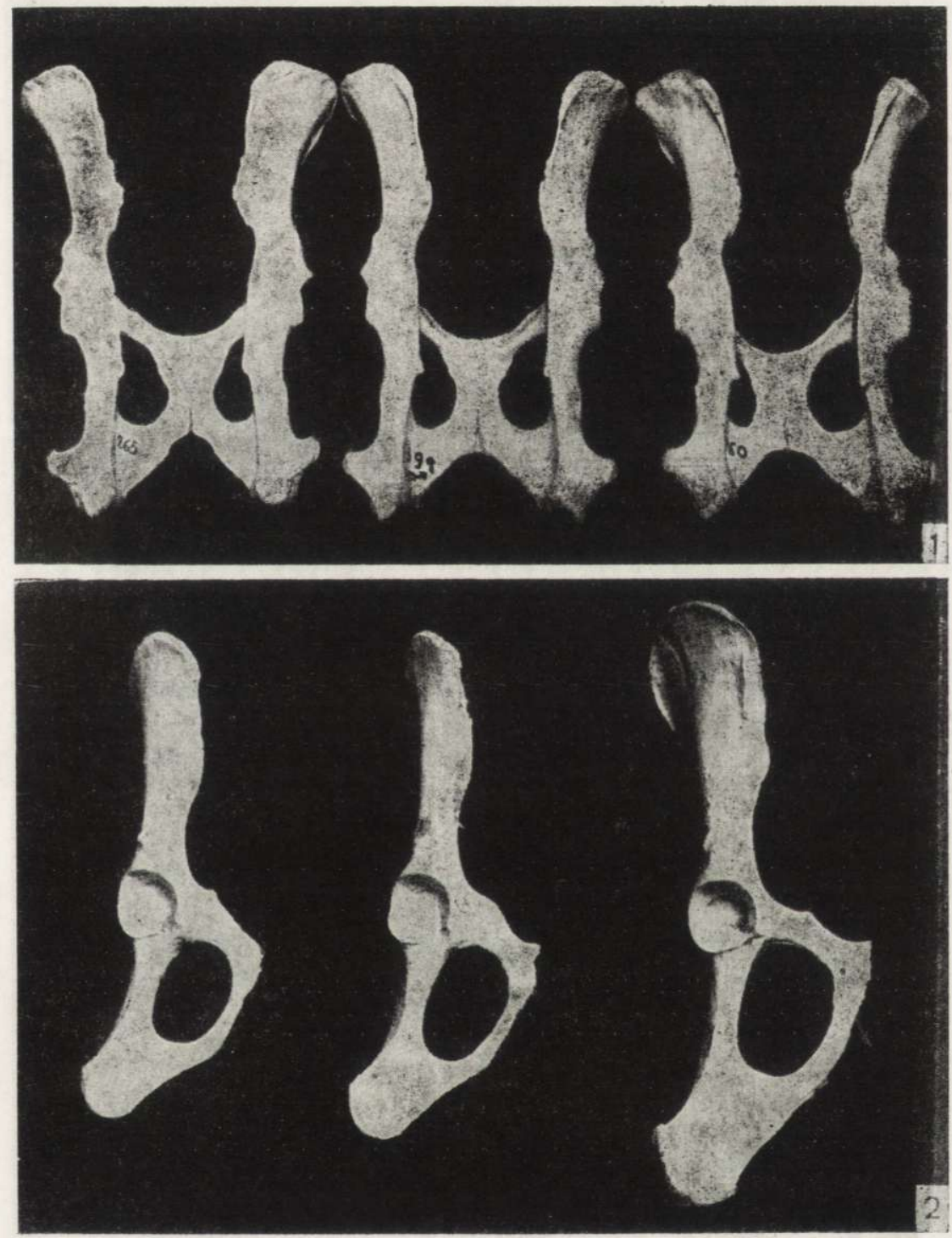

a

b

c

G. Bujalska

S. A. Bujalski phot. 


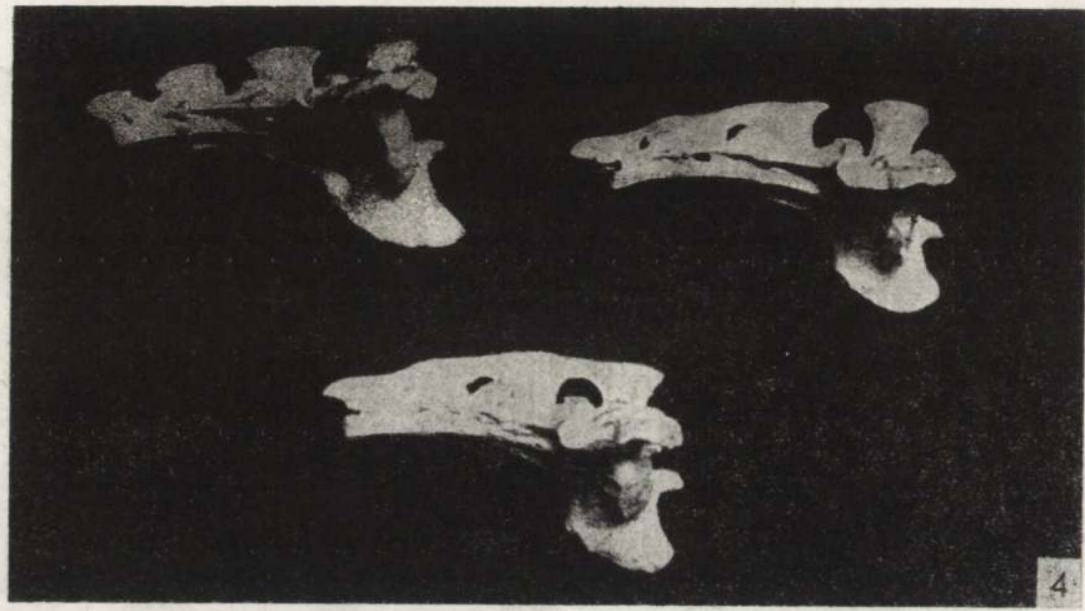

a

c

b
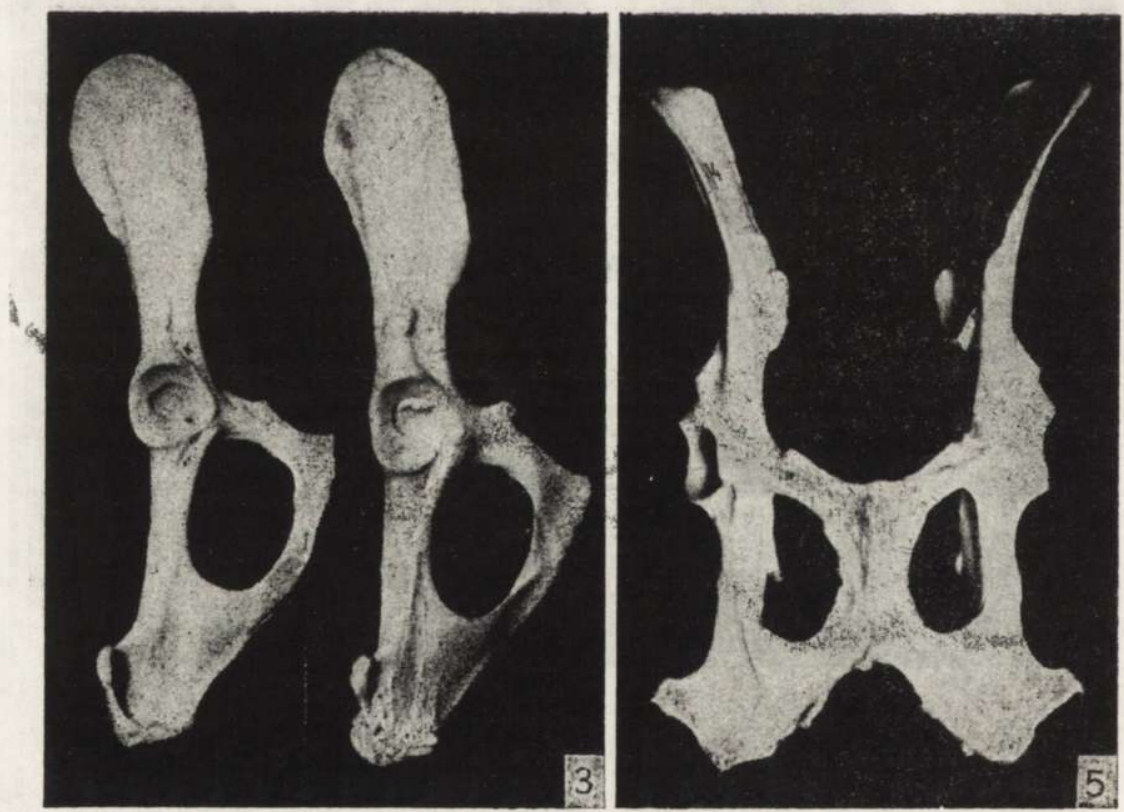

G. Bujalska

S. A. Bujalski phot. 